\title{
Uwagi do projektu uchwały Rady Ministrów w sprawie aktualizacji programu wieloletniego pod nazwą „Program polskiej energetyki jądrowej”
}

Comments to the draft resolution of the Council of Ministers on update of the multi-annual program under the name "Polish nuclear energy program"

\author{
Grzegorz Wiśniewski \\ Instytut Energetyki Odnawialnej \\ e-mail: gwisniewski@ieo.pl \\ ORCID: https://orcid.org/0000-0001-7708-6058
}

Tomasz Kowalak

Ekspert niezależny

Katarzyna Michałowska-Knap

Instytut Energetyki Odnawialnej

e-mail: kmichalowska@ieo.pl

Abstract

The government presented a draft resolution for public consultation on the future of nuclear energy. The article contains detailed expert comments on the text of the resolution and its justification.

Keywords - nuclear energy, investment financing, nuclear reactors, renewable energy sources, buman resources, public consultations, "Polish Nuclear Power Program" 


\section{Uwagi do projektu uchwały Rady Ministrów w sprawie aktualizacji programu wieloletniego pod nazwą „Program polskiej energetyki jądrowej”}

W ramach konsultacji publicznych projektu uchwały Rady Ministrów w sprawie aktualizacji programu wieloletniego pod nazwą „Program polskiej energetyki jądrowej” ogłoszonych 6/08/2020

Data zgłoszenia uwag: 21/08/2020

Zgłaszający uwagi: ECBREC Instytut Energetyki Odnawialnej Sp. z o.o.

Autorzy opinii:

Grzegorz Wiśniewski

Tomasz Kowalak

Katarzyna Michałowska-Knap

Kontakt w sprawie opinii: kmichalowska@ieo.pl, biuro@ieo.pl

\section{Uwagi szczegółowe do tekstu PPEJ oraz jego uzasadnienia}

1) W projekcie PPEJ z 2010 roku ówczesne Ministerstwo Gospodarki zapisało w budżecie PPEJ kwotę $700 \mathrm{mln}$ zł niesprecyzowanych wydatków (wiadomo tylko, że poza etatami znaczna część środków wsparła m.in. lobbing branżowy) i zapowiadało, że elektrownia jądrowa zrealizowana zostanie do 2020 roku. W „Uzasadnieniu” do obecnej propozycji PPEJ stwierdzono (str. 3 dokumentu „Uzasadnienie” przedstawionego do konsultacji), iż „Wstępnie oszacowano potrzeby finansowe urzędu obsługujqcego ministra właściwego ds. energii na lata 2020-34 na kwotę ok. 220 mln zt, a PAA na kwotę ok $400 \mathrm{~m} / \mathrm{n}$ złotych, co daje w przypadku ministerstwa kwotę $14 \mathrm{mln}$ zł średniorocznie, a w przypadku PAA kwotę $26 \mathrm{mln}$ zt średniorocznie". Daje to wyobrażenie o tym, jakie kwoty ma pochłonąć realizacja PPEJ i jakie zostaną przeznaczone na rozwój energetyki jądrowej, tylko z budżetu państwa. Nie jest jasne, jakie koszty poniosą spółki z udziałem Skarbu Państwa i jakie 
konkretnie efekty przyniesie wydatkowanie w ciągu najbliższych 14 lat kwoty 620 mln zł, ponownie wyłącznie na działania przygotowawcze i administracyjne. Jest to niezwykle istotne zwłaszcza w kontekście dotychczasowych działań na rzecz rozwoju energetyki jądrowej, które pomimo zaangażowania ogromnych środków budżetowych oraz spółek z udziałem Skarbu Państwa nie zdołały doprowadzić nawet do wyboru konkretnych lokalizacji potencjalnej elektrowni jądrowej, nie mówiąc już o wyborze technologii czy skali poszczególnych inwestycji.

2) Oprócz rozbudowanych budżetów na działania przedinwestycyjne, bardzo słabą stroną PPEJ jest analiza możliwości finansowania samej inwestycji, sprowadzone do 1 strony tekstu (str. 11) ogólnych informacji oraz banalnej, ogólnikowej konkluzji (str. 46), że „ważnym elementem inwestycji w energetykę jadrowq jest opracowanie efektywnego modelu finansowania, który wraz $z$ istotnym wsparciem państwa pozwoli na możliwe zmniejszenie kosztu kapitału elektrowni jqdrowej". Podane założenia wydają się być oderwane od rynku i realiów gospodarczych oraz analiz alternatywnych ścieżek inwestowania. W tym kontekście ważne jest wskazanie na szerszy kontekst unijny. Polska wynegocjowała łącznie 125 mld EUR z UE w formie dotacji na inwestycje w kolejnej dekadzie oraz 153 mld zł i dodatkowo 34 mld EUR w formie niskooprocentowanych pożyczek (wg KPRM). Z tego minimum 30\% ma być przeznaczone na cele klimatyczne. Chodzi o minimum $175 \mathrm{mld}$ zł dotacji. Parlament Europejski chce podwyższyć skalę wsparcia na zielone inwestycje, co w przeliczeniu na rok dwu-trzy krotnie przekracza wartość wszystkich inwestycji w energetyce w ostatniej dekadzie. Z pewnością dotacje będą mogły być przeznaczone na MŚP i na rozproszone OZE. Przyjmując lewar dla środków publicznych, które indukują inwestycje prywatne, w proporcji 1:4, w okresie 2021-2030 Polska może zrealizować inwestycje w źródła wytwarzania rzędu $700 \mathrm{mld}$ zł, co jest odpowiednikiem ponad $200 \mathrm{GW}$ inwestycji w fotowoltaikę albo ponad $100 \mathrm{GW}$ lądowych farm wiatrowych (np. z elektrolizerami, które staną się komercyjnie dostępne po 2025 roku). Jednocześnie Rada UE w konkluzjach z 25 czerwca wykluczała jakiekolwiek wsparcie finansowe dla energetyki jądrowej z FST. Prace UE nad zieloną taksonomią wskazują, że energetyka jądrowa będzie wyłączona całkowicie ze 
wsparcia publicznego, a to oznacza, że cały wysiłek inwestycyjny w przypadku podjęcia decyzji o budowie elektrowni jądrowej poniesie najpierw polski podatnik (PPEJ), a potem zacznie je ponosić polski konsument energii. Jednocześnie inwestycje $w$ tanie i taniejące OZE wraz z tańszą energią $z$ importu (pominiętą w scenariuszach PPEJ), z powodu braku konkurencyjności energetyki jądrowej najpewniej spowodują, że koszty poniesione podatnika i inwestora staną się kosztami osieroconymi (nie do odzyskania), uszczuplając tym samym ich wykorzystanie w znacznie bardziej rokujących obszarach gospodarki lub $w$ realizacji pilnych i rosnących w dobie epidemii potrzeb społecznych. PPEJ nie uwzględnia zmian na rynku energii i wpływu podejmowanych działań na wartość przedsiębiorstw energetycznych, które miałyby być zaangażowane $w$ realizację programu oraz ich zdolności do finansowania nowych inwestycji. Energetyka jądrowa (podobnie jak i morska energetyka wiatrowa) to zadania odpowiednie dla dużych graczy - krajowych koncernów energetycznych, a wybór opcji inwestycyjnej będzie miał wpływ na wartość rynkową ( $w$ tym giełdową) spółek. Nie tak dawne informacje o porozumieniu grupy Polenergia ze Statoil w sprawie wybudowania farmy wiatrowej na Bałtyku, spowodowały, że kurs akcji Polenergia wzrósł o 10 proc. Podobna informacja - decyzja o ewentualnej budowie elektrowni jądrowej może obniżyć wartość spółek skarbu państwa zaangażowanych w tak ryzykowne i nierentowne przedsięwzięcie. Ten efekt obniży zdolności finansowania projektów budowy elektrowni jądrowych i całkowicie nie jest uwzględniany w projekcie PPEJ.

3) Przedstawiony do konsultacji projekt pokazuje, że w latach 2009-2020 realizacja dotychczasowych PPEJ nie doprowadziła do żadnego przełomu i nie posunęła w żaden sposób do przodu projektu polskiej elektrowni jądrowej. Projekt PPEJ jest nadal pełen ogólników i niedomówień, których po 11 latach inwestowania środków publicznych być już nie powinno. Dla przykładu przy analizie możliwych do zastosowania technologii stwierdza się, iż (str. 12) „W ciqgu ostatnich kilkunastu lat światowy rynek energetyki jqdrowej zdominowaty wielkoskalowe reaktory wodne ciśnieniowe o mocach rzędu 1000-1650 MWe netto. Potwierdzaja to także liczne plany budowy nowych jednostek tego typu i relatywnie niewielka liczba planowanych inwestycji 
z reaktorami wrzqcymi, a także brakiem nowych z reaktorami ciężkowodnymi”. Przy czym Autorzy projektu PPEJ unikają podania jakichkolwiek danych liczbowych odnośnie konkretnych projektów realizowanych, podając tylko w przypisie (str. 12) „Reaktory wodne ciśnieniowe w ostatnich latach zbudowano lub buduje się w Europie m.in. w Finlandii, Francji, Wielkiej Brytanii, Słowacji, Węgrzech, Białorusi, Rosji. W innych częściach świata w USA, Korei Południowej, Zjednoczonych Emiratach Arabskich, Turcji, Bangladeszu, Iranie. Bloki ciężkowodne budowane sq w Europie tylko w Rumunii jako dokończenie projektu wstrzymanego w 1990 r.". Stan rozwoju rynku EJ na świecie w zasadzie można byłoby równie dobrze zaprezentować w ten sam sposób 10 lat temu, przynajmniej jeśli chodzi o Europę (inwestycje w Finlandii czy w Wielkiej Brytanii). Są to projekty realizowane lub planowane od wielu lat (z pewnością od czasu pierwszego PPEJ) i nie jest jasne, skąd Autorzy biorą informacje o „licznych" nowych inwestycjach w tym obszarze i dlaczego na ich podstawie wnioskują o technologii dla Polski, nie mającej (w przeciwieństwie do wymienionych w powyższym cytacie krajów europejskich) żadnych wcześniejszych doświadczeń z energetyką jądrową.

4) W dalszym ciągu, pomimo wieloletnich prac, brak konkretnego wyboru spomiędzy 27 potencjalnych lokalizacji. Autorzy projektu stwierdzają, iż (str. 14) "Biorqc pod uwage stan zaawansowania prac oraz inne uwarunkowania, miejsce budowy pierwszej elektrowni jqdrowej zostanie wybrane spośród lokalizacji nadmorskich.” Nie jest jasne, jakie konkretnie „inne uwarunkowania” decydują o takim wyborze. Jako „lokalizacje nadmorskie” wymienione są Żarnowiec i Lubiatowo-Kopalino a wśród ich zalet wymienia się (str. 14) iż „Przemawiajq za nimi m.in.: znaczne zapotrzebowanie na energię elektrycznq i brak dużych, dysponowalnych źródeł wytwórczych w tym rejonie, dostęp do wody chłodzqcej, możliwość transportu ładunków wielkogabarytowych drogq morskq". Równocześnie nie podaje się żadnych konkretnych liczb i argumentów, np. w jaki sposób EJ przejmie rolę źródła dysponowalnego, jak rozwiązany zostanie problem przesyłu energii, biorąc pod uwagę topologię sieci w regionie. Jeśli chodzi o możliwość transportu ładunków wielkogabarytowych, to w bezpośrednim sąsiedztwie Żarnowca / Lubiatowa brak większych portów morskich, które mogłyby obsługiwać 
statki z takimi transportami (co prawda tu też brak informacji o jakie konkretnie ładunki miałoby chodzić i jakie są w tej kwestii wymagania). Jeśli jednak założymy dostawę np. do portu w Gdyni lub Gdańsku, a następnie drogą lądową, to inne rozważane lokalizacje mogłyby mieć przewagę nad preferowanymi, ze względu na lepsze istniejące połączenia na lądzie. Jest to tylko jeden z przykładów, jak powierzchowne i ogólnikowe są dotychczasowe analizy, będące efektem wieloletnich prac. Wybór ten zresztą pozostaje w sprzeczności z zadaniami, o których mowa w rozdziale 2.2 Rozwój infrastruktury (str. 18), gdzie wymienia się szereg potrzeb inwestycyjnych w zakresie rozbudowy infrastruktury zarówno elektroenergetycznej jak i transportowej lądowej w przypadku lokalizacji EJ w Polsce północnej.

5) Autorzy projektu stwierdzają m.in. iż „Miejsca prawdopodobnej budowy elektrowni jqdrowych sq tożsame z lokalizacjami określonymi w Programie PEJ z 2014 r. Brak zmian w tym zakresie sprawia, że rodzaj i skala potencjalnego oddziaływania na środowisko pozostajq takie same, dlatego nie jest wymagane przeprowadzenie ponownej strategicznej oceny oddziaływania na środowisko." (str. 13). W ciągu ostatnich lat mamy w Polsce do czynienia np. z rosnącym problemem suszy, który może mieć znaczenie w odniesieniu do szeregu lokalizacji. Zmieniło się wiele uwarunkowań zewnętrznych o charakterze środowiskowym, społecznym oraz rynkowym, które mają znaczenie przy analizie wariantów alternatywnych. Zwłaszcza wobec spadku kosztów technologii OZE i ich rozwoju w ciągu ostatnich 5 lat, rzetelne rozważenie wariantów alternatywnych jest konieczne. Stąd, w przypadku decyzji o kontynuacji PPEJ strategiczna ocena oddziaływania na środowisko powinna być przeprowadzona ponownie i od podstaw (nie zaś tylko znowelizowana), aczkolwiek już odniesieniu do określonych lokalizacji i technologii, nie zaś ogólników, jakie prezentowane są w obecnej propozycji rządowej.

6) Na str. $\mathbf{2 0}$ mamy do czynienia z dość interesującą uwagą „Należy również zwrócić uwagę, że w rejonie rekomendowanej jako pierwszej lokalizacji EJ przewidywany jest także rozwój morskiej energetyki wiatrowej. Wyprowadzenie mocy zarówno z elektrowni jqdrowej i ze źródeł morskich jest realizowane i w pełni wykonalne zgodnie z PRSP. Wyprowadzenie mocy z obu źródeł zostanie zrealizowane poprzez ustalenie obu miejsc przyłaczenia 
w oddaleniu od siebie." (podkreślenie recenzenta). Już obecnie PSE Operator wydał warunki przyłączenia dla prawie $8 \mathrm{GW}$ morskiej energetyki wiatrowej w Słupsku i Żarnowcu. Projekt o mocy 1045,5 MW (przyłączenie w Żarnowcu) posiada już umowę przyłączeniową przewidującą rozpoczęcie dostarczania energii pod koniec 2027 roku (źródło: baza danych IEO w oparciu o dane PSE). Podłączenie zatem nowych mocy na tym obszarze, o ile zapewne jest możliwe, będzie jednak wymagało znaczących inwestycji w infrastrukturę elektroenergetyczną przesyłową, o ile punkty przyłączenia miałyby być (cokolwiek to znaczy) „w oddaleniu od siebie”. Koszty tego rozwiązania nie są $w$ pełni odzwierciedlone $w$ analizach PPEJ pomimo tego, że autorzy zastrzegają, że przy wyznaczaniu strategii państwo wykorzystuje m.in. „metodykę kosztu całkowitego” różniącą się istotnie od (wąskiego) inwestorskiego rachunku ekonomicznego.

7) Biorąc pod uwagę obecny stan przygotowania projektu polskiej EJ, zadania zmierzające do kształcenia kadr są stanowczo przedwczesne, tym bardziej, że jak sami Autorzy projektu PPEJ potwierdzają (str. 18) „Ramowy plan rozwoju zasobów ludzkich na potrzeby energetyki jądrowej” został już opracowany. Nie jest zatem jasne, co na obecnym stadium planowania polskiej EJ można byłoby chwilowo zrobić, a projekt PPEJ nie przedstawia dostatecznej liczby konkretnych informacji. Warto zwrócić uwagę na fakt, że tego typu plany nie są przygotowywane za pieniądze publiczne dla innych gałęzi energetyki, takich jak OZE, których rynek dynamicznie się rozwija i potrzebuje (już obecnie) specjalistów, a konkretne cele wyznaczające rozwój tego rynku są od dawna ustalone. W szczególności dotyczy to np. morskiej energetyki wiatrowej, gdzie plany wdrożenia są znacznie bardziej realistyczne, a specjaliści potrzebni będą szybciej niż w energetyce jądrowej. Brak również na poziomie rządowym takich działań dla OZE jak np. (str. 17) „aktualizacja treści podręczników i podstaw programowych w szkołach podstawowych i ponadpodstawowych innych niż techniczne i zawodowe pod kq̨em przekazywanej wiedzy na temat energetyki jqdrowej". Jest to nieuzasadnione (także rolą jaką ew. EJ odegra w przyszłym miksie energetycznym) faworyzowanie energetyki jądrowej oraz dyskryminacja innych źródeł energii, co do których takich zapisów w dokumentach na poziomie rządowym brak, a bez wątpienia 
poprawa jakości wiedzy przekazywanej na ich temat stanowiłaby istotne wsparcie w ich rozwoju.

8) Przedstawiony na str. $\mathbf{2 7}$ harmonogram inwestycji jest nierealistyczny, biorąc pod uwagę fakt, że obecnie nie wiadomo jeszcze, gdzie EJ1 i EJ2 konkretnie miałyby się znajdować i w jakiej technologii miałyby być zrealizowane. Kolejność proponowanych działań jest zresztą niejasna, podobnie jak związane z nimi kamienie milowe, np. podpisanie umowy z EPC i decyzja środowiskowa miałyby nastąpić w 2022 roku.

9) Mierniki realizacji (str. 32) programu są nieadekwatne; w większości (jak się zdaje) jest to harmonogram wydatkowania środków z programu (np. dla zadania Przygotowanie inwestycji towarzyszq̨cych lub Zaangażowanie krajowego przemysłu). Natomiast brak dostatecznych wskaźników efektywności wykorzystania tych środków.

10) Na potrzeby oceny ekonomiki wprowadzenia EJ do systemu wykorzystano „metodykę modelu kosztu całkowitego KSE, opracowanego przez Biuro Petnomocnika Rzqdu ds. Strategicznej Infrastruktury Energetycznej, przy współpracy merytorycznej i analitycznej Polskich Sieci Elektroenergetycznych" (str. 36). Równocześnie zostały przedstawione 4 scenariusze struktury generacji do roku 2045. Żaden z nich nie pokrywa się z obecnymi dokumentami strategicznymi lub ich projektami (KPEiK i potrzeba jego nowelizacji z uwagi na aktualne wymagania Komisji Europejskiej ${ }^{1}$ w zakresie udziałów OZE i plany UE podniesienia w 2021 roku celów na OZE na 2030 rok). Autorzy stwierdzają nawet wprost, iż „Przedstawione wyniki modelowania sektora elektroenergetycznego majq charakter analityczny i nie sq scenariuszami alternatywnymi do prognoz przedstawionych w projekcie Polityki energetycznej Polski do 2040 (PEP2040)." (str. 36) Nie wyjaśniają jednak dlaczego akurat na takie 4 scenariusze się zdecydowali, zwłaszcza, że aż w 3 wariantach uwzględnia się budowę elektrowni Ostrołęka C w oparciu o węgiel kamienny, a w jedynym wariancie w którym jej brak zakłada się utrzymanie blokady rozwoju lądowej energetyki wiatrowej. Autorzy nie wyjaśniają dostatecznie jakie były kryteria (determinanty) budowy scenariuszy. Stwier-

\footnotetext{
${ }^{1}$ Zalecenie Komisji Europejskiej C(2019) 4421 w sprawie polskiego KPEIK z 18 czerwca 2019 roku
} 
dzają (str. 36), że „jako podstawę optymalizacji wykorzystano prognozę zapotrzebowania na energię elektrycznq oraz dane dot. planowanych odstawień istniejqcych mocy wytwórczych zgodne z Planem rozwoju w zakresie zaspokojenia obecnego i przyszłego zapotrzebowania na energię elektrycznq na lata 2021-2030 (PRSP'20). Ze względu na konieczność zapewnienia bezpieczeństwa energetycznego KSE przyjęto założenie o samowystarczalności generacji krajowej, tj. zerowym bilansie importowo -eksportowym. Założeniem obligatoryjnym każdego scenariusza jest wypełnienie sektorowego celu OZE dla elektroenergetyki w roku 2030, wynoszqcego 33,32\% udziału OZE w produkcji energii elektrycznej netto." W związku z tym po pierwsze, nie wiadomo czym stymulowany jest rozwój po 2030 roku. Jest to tym bardziej istotne, że scenariusze zakładające brak energetyki jądrowej dopiero po 2030 roku zaczynają wykazywać rosnący koszt zewnętrzny i całkowity. Ponadto zerowy bilans eksportowo-importowy jest założeniem mało realistycznym w praktyce. Zarazem przyjęty miks energetyczny jest całkowicie sztuczny, a w wariancie II sztucznie zawyżono koszty, eliminując najtańsze OZE, tzn. lądową energetykę wiatrową (przewidując, że blokada 10h zostanie utrzymana).

11) Przyjęte założenia techniczno-ekonomiczne (Załącznik 5) nie są w pełni uzasadnione. Źródłem danych było Biuro Pełnomocnika Rządu ds. Strategicznej Infrastruktury Energetycznej, na podstawie prognoz National Renewable Energy Laboratory (NREL) - ATB'1940, International Energy Agency (IEA) WEO'1941 oraz Polskich Sieci Elektroenergetycznych (PSE) - PRSP'2042. Jeśli chodzi o energetykę jądrową, trudno jest kwestionować te źródła, natomiast przyjęte założenia budzą wątpliwości w odniesieniu do OZE w warunkach polskich. Tak np. jeśli chodzi o nakłady inwestycyjne (tab. 1, str. 51) koszty dla PV są znacząco zawyżone. Dla wielkoskalowych inwestycji (a takie mają największe znaczenie w systemie) można już obecnie przyjąć $2500 \mathrm{mln}$ PLN/GW, a nie podane $w$ tabeli 3900 , ponadto wartość ta będzie znacząco spadać. Jeśli chodzi o współczynniki wykorzystania mocy (tab. 5, str. 53), to ponownie mamy tu do czynienia z niedocenianiem energetyki wiatrowej morskiej. Zakładając wejście projektów wiatrowych offshore do systemu ok. 2025 roku już obecnie można założyć współczynnik wykorzystania mocy na 
poziomie $50 \%$, a oczekuje się, że nowe modele turbin mogą osiągnąć rezultaty znacznie powyżej $60 \%$. Na Morzu Bałtyckim mamy wyjątkowo dobre warunki wiatrowe i nie ma powodu, aby konstruować tak konserwatywne scenariusze. Przy ciągłym spadku kosztów OZE, warto podkreślić, że obserwowany jest trwały wzrost kosztów elektrowni jądrowych. Warto podkreślić, że w 2010 roku Ministerstwo Gospodarki oceniało nakłady inwestycyjne na pierwszą elektrownię jądrową sprowadzone na 2020 rok (elektrownia miała zacząć pracę 1 stycznia 2022 roku) na ok. 2,25 mld EUR/GW (10 mln zł/GW), podczas gdy w obecnej wersji projektu PPEJ nakłady te wynoszą już 22,3 mln zł/GW (str. 51) - wzrost o ponad 100\% w ciągu dekady. Warto też zauważyć, że jeszcze w 2018 roku Ministerstwo Energii oceniało nakłady inwestycyjne na budowę nowej elektrowni jądrowej na 12-14 mld zł/GW. Nie wiadomo zatem na jakiej podstawie i z jakich powodów jednostkowe nakłady inwestycyjne zaraz po 2020 roku mają spadać, w sytuacji gdy świat ma szczyt inwestycji jądrowych za sobą, a wymagania bezpieczeństwa wobec tych obiektów rosną (choćby z powodu zmian klimatycznych).

\section{Uwagi ogólne o charakterze systemowym oraz istotne zagadnienia po- minięte w PPEJ}

\section{Terminologia podstawowa}

Koronnym argumentem na rzecz wdrożenia Programu polskiej energetyki jądrowej (Programu PEJ) jest powtarzana niezmiennie od pierwszej wersji tego Programu z 2014 r. teza oparcia go na trzech filarach, jakimi są bezpieczeństwo energetyczne, klimat i środowisko oraz ekonomia.

Należy odnotować, że energetyka jądrowa w wersji przewidywanej do wdrożenia w Polsce jest w istocie częścią składową elektroenergetyki i jako taka nie powinna abstrahować od pojęć zdefiniowanych w akcie prawnym fundamentalnym dla tego sektora, jakim jest ustawa z 10 kwietnia 1997r. Prawo energetyczne (Dz.U. z 2020 r. poz. 833,843 i 1086), dalej: uPe.

Zgodnie z brzmieniem art. 2 pkt 16 uPe, określenie "bezpieczeństwo energetyczne” oznacza „stan gospodarki umożliwiajq̨cy pokrycie bieżqcego i perspektywicznego 
zapotrzebowania odbiorców na paliwa i energię w sposób technicznie i ekonomicznie uzasadniony, przy zachowaniu wymagań ochrony środowiska".

Tym samym, termin „bezpieczeństwo energetyczne” co do zasady łączy w sposób równorzędny wszystkie trzy aspekty: techniczny, ekonomiczny i ekologiczny. Operowanie przez autorów Programu konstrukcją „trzech filarów”, spośród których wyróżnione jest „bezpieczeństwo energetyczne” wskazuje na błędne zawężenie pojęcia bezpieczeństwa energetycznego do „bezpieczeństwa technicznego” i ignorowanie systemu pojęciowego obecnego w polskim porządku prawnym od 1997r., tj. od dwudziestu trzech lat ${ }^{2}$.

\section{Energetyka jądrowa vs bezpieczeństwo techniczne}

Bezpieczeństwo techniczne systemu elektroenergetycznego należy rozpatrywać w czterech aspektach. Są to:

a) Wystarczalność potencjału, wyrażana jako bilans energii, zrównoważony w perspektywie horyzontu planowania.

b) Dostępność zasobów i ich dyspozycyjność, wyrażana jako bilans mocy, zrównoważony w perspektywie horyzontów planowania.

c) Elastyczność, czyli zdolność do reagowania na bieżące zmiany krótkookresowe oraz długookresowe trendy.

d) Odporność na zakłócenia, których źródłem mogą być siły natury oraz czynnik ludzki wynikający z działania w złej wierze lub w wyniku niekompetencji, w tym niedocenienia sił natury).

Ad a) Wystarczalność potencjału

Koncepcja Programu PEJ stanowi próbę odpowiedzi na zapotrzebowanie zapewnienia wystarczalności potencjału wytwórczego, stojącego wobec wyzwań związanych zasobem wytwórczym aktualnie wykorzystywanym, takich jak:

$>$ jego starzenie się techniczne,

\footnotetext{
${ }^{2}$ Dodatkowego podkreślenia wymaga, że podobnie błędne jest kategoryzowanie elementów bezpieczeństwa energetycznego zgodnie z koncepcją potrzeb opisaną trójkątem Maslowa, wg której potrzebą fundamentalną jest zapewnienie bezpieczeństwa technicznego, potrzebą wyższą jest ekonomia, podporządkowana dyktatowi technicznemu, a przestrzeń na dyskusję o ekologii otwiera się dopiero po zaspokojeniu dwóch potrzeb poprzednich.
} 
> rosnące ograniczenia możliwości jego wykorzystywania wynikające z:

- polityki klimatycznej KE (limity emisji $\mathrm{CO}_{2}$ ) oraz

- wymagań środowiskowych (limity emisji pyłów, SOx, NOx, Hg, benzo-

(a)pirenów i in. substancji szkodliwych),

a także spodziewany wzrost zapotrzebowania na energię elektryczną, wynikający z postępującego wzrostu zamożności społeczeństwa oraz postępującej elektryfikacji transportu i ogrzewnictwa.

W liczbach bezwzględnych Program PEJ może wydawać się najprostszym skutecznym rozwiązaniem spodziewanego deficytu w bilansie energii z uwagi na fakt, że to na Państwie spoczywa odpowiedzialność za jego zapewnienie, a inwestycje w wielkoskalowe źródła EJ mogą być realizowane wyłącznie przy decydującej roli Państwa w tym procesie. Dzięki temu wydawać się może, że realizacja Programu PEJ pozwala zachować Państwu pełną kontrolę nad realizacją ciążącego na nim obowiązku. Jest to jednak nadzieja złudna, gdyż ocena bezpieczeństwa energetycznego ograniczona do bilansu energii ignoruje praktycznie wszystkie pozostałe aspekty bezpieczeństwa technicznego, nie wspominając o jego aspektach ekonomicznym i ekologicznym.

Ad b) Dostępność zasobów

Program PEJ przewiduje budowę od 6 do 9 GWe zainstalowanej mocy jądrowej w formie od czterech do dziewięciu wielkoskalowych reaktorów jądrowych o mocy jednostkowej rzędu 1000-1650 MWe netto.

Z jednej strony oznacza to petryfikację KSE, działającego w formule scentralizowanej, z drugiej nie daje satysfakcjonującej odpowiedzi, w jaki sposób zapewniany ma być bieżący bilans mocy. Już aktualnie obserwowany jest wzrost amplitudy dobowych zmian obciążenia KSE, będący wynikiem braku mechanizmów stymulujących odbiorców do racjonalizacji zachowań. Rozwój e-mobility niesie dodatkowe ryzyko pogłębienia tego procesu. System scentralizowany, oparty na skupionych wielkoskalowych źródłach wytwórczych, niezależnie od zastosowanej technologii, czy będą to źródła jądrowe, węglowe, gazowe, czy wiatrowe off-shore, pociąga za sobą konieczność transportu wyprodukowanej energii za pośrednictwem odpowiednio rozbudowanej sieci przesyłowej, podprzesyłowej (110 kV) i dystrybucyjnej, ale także konieczność pokrycia związanych z tym strat przesyłowych rosnących z kwadratem 
prądu, a zatem najsilniej w okresach szczytowego obciążenia. Tym samym, rozbudowa zdolności wytwórczych w formule skupionej jako odpowiedź na rosnące zapotrzebowanie finalne sama z siebie wymusza dodatkowy wzrost zapotrzebowania na energię wprowadzaną do sieci i na inwestycje sieciowe.

Planując rozwój zdolności wytwórczych w formule scentralizowanej (wielkoskalowej) nie wolno więc abstrahować od praktycznych możliwości adekwatnej rozbudowy sieci przesyłowych. Że nie jest to zagadnienie trywialne, dowodzi praktyka. Przepływy kołowe, jakie odczuwa KSE, są rezultatem motywowanego protestem społecznym braku możliwości rozbudowy połączeń przesyłowych pomiędzy północną częścią Niemiec a Bawarią. Podobnie w Polsce, syndrom NIMBY, ujawniony na przykładzie planowanej inwestycji w linię 400 kV Kozienice - Ołtarzew, w praktyce zablokował jej realizację. Każe to z dużym niepokojem oczekiwać możliwości zapewnienia odbiorcom końcowym energii elektrycznej dostępności mocy z nowych źródeł jądrowych, rozbudowanych do skali proponowanej w programie PEJ.

\section{Ad c) Elastyczność}

Wielkoskalowe źródła cieplne (a EJ jest formą takiego źródła) są trudno regulowalne ze względu na stałe czasowe nagrzewania grubościennych elementów konstrukcyjnych, takich jak rurociągi pary świeżej i korpusy turbin. Wielkoskalowa energetyka jądrowa nie jest więc efektywnym rozwiązaniem problemu zapewnienia nadążności za szybko zmieniającym się poziomem generacji ze źródeł pogodowo-zależnych.

W dyskusji publicznej ostatnich lat podnoszony jest problem niekontrolowanej zmienności generacji energii elektrycznej ze źródeł pogodowo-zależnych i budowana na tej tezie konieczność ich rezerwowania przez generację gazową. Teza ta jest o tyle błędna, że nie jest prawdą iż generacja pogodowo-zależna jest nieprognozowalna, problemem jest jedynie jej niezależność od zmienności obciążenia. Wielkoskalowa energetyka jądrowa nie rozwiąże problemu bieżącego równoważenia bilansu mocy wyeksponowanego jednocześnie na dwie rosnące zmienności: obciążenia oraz generacji pogodowo-zależnej. Bez wprowadzenia skutecznych narzędzi zarządzania popytem lub magazynowania energii nadal pozostanie konieczność zachowania na znaczną skalę generacji gazowej, przy jednoczesnym prowadzeniu jednostek jądrowych w głębokiej rezerwie obciążenia. 
Rozwiązaniem racjonalnym z punktu widzenia zapewnienia elastyczności systemu jest jego skalowalność, czyli rozbudowa KSE „małymi krokami”, w sposób nadążny za wzrostem zapotrzebowania i jednocześnie za dokonującym się postępem technologicznym. Scentralizowany program budowy źródeł wielkoskalowych jest tego zaprzeczeniem. Petryfikuje poziom technologiczny wdrażanych rozwiązań, zwłaszcza przy założeniu wdrażania „sprawdzonych rozwiązań”. Jest zrozumiałe, że skala koniecznych do poniesienia nakładów inwestycyjnych zniechęca do eksperymentowania z technologiami dopiero rozwijanymi, ale wyklucza to możliwość skorzystania z premii nowości. Jest to mechanizm finansowania krajów bogatych, które stać na rozwijanie nowych technologii, przez kraje biedniejsze, decydujące się na zakup technologii „sprawdzonych”.

Odrębnym problemem jest utrata zdolności do elastycznego reagowania na trendy, jakie dopiero się ujawnią. Wieloletni cykl inwestowania w EJ, podlegający - jak wykazuje praktyka Wielkiej Brytanii i Finlandii - dodatkowym wieloletnim opóźnieniom, powoduje pojawienie się ryzyka, że w okresie finalizowania Programu PEJ aktywa wytworzone w jego wyniku nie znajdą miejsca na rynku w wyniku upowszechnienia całkowicie odmiennych form zaspokojenia potrzeb energetycznych obywateli i gospodarki.

Ad d) Odporność na zakłócenia

Najbardziej jaskrawym przejawem zagrożenia bezpieczeństwa technicznego dostaw energii ze strony wielkoskalowych źródeł energii elektrycznej, a w szczególności EJ, jest ich ekspozycja na zakłócenia. Bez znaczenia pozostaje w tym przypadku zapewnienie wewnętrznego bezpieczeństwa pracy samego reaktora (w tym np. niemożność stopienia rdzenia, zapewniana przez niektóre konstrukcje, czy odporność osłony reaktora na ataki terrorystyczne). Problemem kluczowym jest praktyczny brak możliwości zapewnienia bezpieczeństwa wyprowadzenia mocy z elektrowni wielkoskalowej. I znowu dotyczy to wszystkich technologii wielkoskalowych, ale w przypadku EJ nabiera szczególnego znaczenia ze względów psychologicznych. Znane są alarmistyczne doniesienia o awariach w elektrowniach jądrowych, które w rzeczywistości polegały np. na pożarze transformatora blokowego, czyli elementu całkowicie „zewnętrznego" względem technologii nuklearnej, za to wspólnego dla wszystkich wielkoskalowych elektrowni cieplnych. 
Rozdzielnie wyprowadzenia mocy z wielkoskalowych elektrowni cieplnych, takie jak Rogowiec, Kozienice czy Krajnik, są eksponowane na atak terrorystyczny/sabotaż, możliwy do przeprowadzenia przy zastosowaniu bardzo prostych w użyciu i tanich środków technicznych.

Linie przesyłowe, wyprowadzające moc z elektrowni wielkoskalowych, całkowicie bezbronne na atak, są dodatkowo eksponowane na ekstremalne zjawiska pogodowe, czego przykładem może być black'out szczeciński z kwietnia 2008r.

Awaria techniczna jednej z linii przesyłowych łączących Szwajcarię z Włochami, w wyniku kaskadowego rozprzestrzenienia się jej skutków doprowadziła do black'outu całego Półwyspu Apenińskiego latem 2003r.

Ataki terrorystyczne na linie przesyłowe miały już miejsce w Europie w ostatnich latach (np. linie zasilające Półwysep Krymski) i nie ma przesłanek, by oczekiwać, że ryzyko ich wystąpienia będzie malało, wręcz przeciwnie.

Jest truizmem, że we wszystkich systemach zapewnienia bezpieczeństwa najbardziej zawodny jest czynnik ludzki. W przypadku EJ efekt psychologiczny związany z ew. zagrożeniem radiologicznym jest czynnikiem w sposób szczególny zwiększającym potencjalne „zainteresowanie” ze strony osobników psychicznie niezrównoważonych oraz ośrodków terrorystycznych, co potwierdzają już wielokrotne doniesienia z Belgii oraz Holandii.

Ryzyka techniczne, immanentnie związane z elektroenergetyką wielkoskalową, dodatkowo nasilone w odniesieniu do EJ, mogą być moderowane w praktyce wyłącznie poprzez sukcesywne rozproszenie zasobów, pozwalające na skrócenie drogi transportu energii od miejsca wytworzenia do miejsca konsumpcji (zmniejszenie uzależnienia od dalekosiężnego transportu energii) oraz na zminimalizowanie „atrakcyjności” elementów infrastruktury elektroenergetycznej z punktu widzenia celów ew. terrorysty. Taką formą zwiększenia bezpieczeństwa energetycznego Polski z wykorzystaniem EJ mogłoby być wdrożenie programu implementacji SMR-ów, (małych jednostek bezobsługowych, wykorzystujących bardzo „słaby” materiał rozszczepialny), ale to nie jest przedmiotem Programu PEJ. 
Rutynowym narzędziem zapewnienia odporności KSE na doraźne zakłócenia jest zachowywanie kryterium N-13. Oznacza to jednak, że w przypadku, kiedy w KSE pracuje jednostka o mocy rzędu 1,5 GW, pozostałe pracujące jednostki wytwórcze muszą być prowadzone poniżej ich znamionowego punktu pracy na sumaryczną moc nie mniejszą niż wspomniane $1,5 \mathrm{GW}$. Jest to pasmo wirującej rezerwy mocy niezależne od opisanego powyżej w pkt. Ad c), dedykowanego do zapewnienia nadążności za bieżącymi zmianami obciążenia.

Analogiczne wyzwanie staje wobec układu przesyłowego, który także musi zapewniać spełnienie kryterium N-1, a co oznacza odpowiednie poszerzenie programu rozbudowy sieci przesyłowej i poszerzenie zakresu potencjalnych konfliktów z lokalnymi społecznościami.

W tym kontekście teza o zwiększeniu bezpieczeństwa energetycznego Polski w jego wymiarze technicznym poprzez wdrożenie Programu PEJ jest całkowicie pozbawiona uzasadnienia.

\section{Klimat i środowisko}

Naczelnym argumentem mającym uzasadnić celowość wdrożenia w Polsce wielkoskalowej EJ jest jej bezemisyjność.

W tym kontekście jedyną tezą prawdziwą jest brak emisji $\mathrm{CO}_{2}$ z bieżącej produkcji energii. Pomijany jest natomiast problem wpływu na środowisko układów chłodzenia, wspólny dla wszystkich technologii elektroenergetyki cieplnej, w następujących aspektach:

a) Zapotrzebowanie na wodę

b) Zwiększona emisja metanu ze zbiorników wodnych podlegających podgrzewaniu, zachodząca w wyniku nasilania procesów gnilnych (efekt analogiczny do zachodzącego w związku z pracą wielkich przepływowych elektrowni wodnych, gdzie obszary zwiększonej produkcji metanu dotyczą stref zmienności linii brzegowej zbiorników)

c) Depozyt ciepła do środowiska

\footnotetext{
${ }^{3}$ Warunek zapewnienia niezakłóconej pracy całego systemu w przypadku nagłej awarii jej dowolnego elementu składowego (źródła lub linii), w praktyce źródła o największej mocy lub linii o największym obciążeniu
} 
Względy wymienione w pkt a oraz b nie dotyczą EJ chłodzonej wodą morską, natomiast pkt. b dodatkowo nie dotyczy EJ z zamkniętym obiegiem chłodzenia. W przypadku rozważanej lokalizacji w Bełchatowie nie może być jednak ignorowany problem zapotrzebowania na wodę.

Odrębnym zagadnieniem jest depozyt ciepła (pkt c), aktualnie pozostający poza obszarem zainteresowania polityki klimatycznej. Nie można jednak wykluczyć, że w perspektywie pięciu dekad okresu realizacji Programu PEJ zostanie ono włączone do listy obostrzeń, zwłaszcza w sytuacji, gdy większość obecnie eksploatowanych EJ zbliży się do końca swojego resursu, a upowszechnione zostaną alternatywne formy zaspokojenia potrzeb energetycznych, nie wykorzystujące obiegu Rankine'a. Dowodem na to, że wymogi klimatyczne są procesem dynamicznym, a lista obostrzeń środowiskowych podlega sukcesywnej rewizji (poszerzaniu) jest np. pojawienie się wymogu kontroli emisji $\mathrm{Hg}$.

\section{Ekonomia}

Rachunek inwestycji w EJ nie uwzględnia kosztów zewnętrznych względem generacji EJ, jakim jest konieczność rozbudowy systemu przesyłowego, nieuchronnej przy utrzymaniu scentralizowanego modelu funkcjonowania KSE, a możliwego do uniknięcia przy przejściu na model rozproszony, a także kosztu utrzymywania rezerw w alternatywnych źródłach niezbędnych do bieżącego bilansowania KSE (wbrew lansowanej w Programie PEJ tezie o możliwości zrezygnowania z rozwoju źródeł gazowych jako korzyści z rozwoju EJ) oraz źródłach i liniach niezbędnych do zapewnienia rezerwowania mocy oraz spełnienia kryterium N-1.

Co więcej, decyzja o podjęciu programu PEJ oznacza:

- zaangażowanie znacznych środków budżetowych na jego realizację, a w przypadku ew. niepowodzenia programu, niezależnie od przyczyny - ich zmarnowanie

- ze względu na ograniczoność zasobów dysponowalnych - drenaż rynku ze środków finansowych niezbędnych do rozwoju alternatywnych rozwiązań przyszłościowych, a w konsekwencji petryfikację ekspozycji KSE na ryzyka opisane w pkt. 1. 


\section{Polityka społeczna (alternatywne zatrudnienie)}

Realizacja programu PEJ wymaga aktywizacji relatywnie wąskiej grupy firm wykonawczych (generalnie podwykonawców względem zagranicznej firmy realizującej inwestycję w technologii dotychczas w Polsce nie stosowanej). Oznacza to, że wymuszone polityką klimatyczną zastąpienie energetyki węglowej przez EJ, oznaczałoby pozostawienie pogórniczej społeczności śląskiej bez realnej perspektywy alternatywnego zatrudnienia, ze wszystkimi negatywnymi konsekwencjami społecznymi takiego procesu.

Alternatywą znacznie bardziej atrakcyjną z punktu widzenia polityki społecznej jest otwarcie niszy biznesowej wymagającej wysokiego zatrudnienia ale przy mniej wymagających kwalifikacjach dla zintensyfikowania rozwoju energetyki pogodowo-zależnej, dla której zrozumienie już jest na Śląsku obecne.

\section{Bezpieczeństwo polityczne w wyniku dywersyfikacji bazy paliwowej}

Dywersyfikacja bazy paliwowej poprzez włączenie do koszyka nośników energii pierwotnej paliwa jądrowego jest jedynie pozornie atrakcyjna z punktu widzenia bezpieczeństwa energetycznego.

Dla odbiorców krytyczna jest pewność zasilania w miejscu konsumpcji energii, natomiast praktycznie bez znaczenia pozostaje okoliczność, które z ogniw w całym łańcuchu dostaw energii, i z jakiej przyczyny, uległo awarii pozbawiając odbiorcę dostępu do energii.

Decyzja o realizacji Programu PEJ oznacza uzależnienie polityczne i ekonomiczne od zewnętrznych dostawców paliwa jądrowego w całym horyzoncie funkcjonowania programu (kolejne pięćdziesiąt lat). Jak trudno przewidywalna w takim horyzoncie czasowym jest sytuacja polityczna na świecie, niech będzie przestrogą porównanie stanu obecnego i sytuacji sprzed pięćdziesięciu lat (z roku 1970 - dwa lata po interwencji w Czechosłowacji, trwająca wojna w Wietnamie, dwa lata przed rozpoczęciem w Polsce programu budowy elektrowni opartych na blokach 200MW). W tym kontekście nie może być kontrargumentem dotychczasowa historia energetyki jądrowej na świecie. 
Natomiast ew. próba moderowania tego ryzyka przez utworzenie zapasów paliwa na cały okres funkcjonowania Programu (technicznie możliwa) miałaby wpływ na pogorszenie ekonomiki projektu.

Należy w tym miejscu odnotować, że praktycznie jedynym nośnikiem energii pierwotnej wolnym od ryzyka zablokowania dostępu jest energia wiatru i promieniowania słonecznego, wykorzystywane przez źródła pogodowo-zależne.

\section{Wzorce innych państw}

Przywoływanie we Wprowadzeniu do Programu PEJ przykładów Francji i Szwecji jako krajów w których EJ decyduje o niskiej emisji średniej $\mathrm{CO}_{2}$ jest przejawem demagogii. W każdym z tych krajów motywacja do rozwoju EJ miała podstawy inne niż energetyczno-klimatyczne i była związana głównie z podłożem militarnym, gdzie ekonomia ma znaczenie drugorzędne, a decyzje o rozwoju EJ były podejmowane w całkowicie innej rzeczywistości gospodarczej i technologicznej. Dodatkowo, np. Francja planuje odejście od EJ w miarę starzenia się tego zasobu, co oznacza, że pomimo dysponowania wyspecjalizowanym potencjałem intelektualnym, którego w Polsce obecnie w takim stopniu nie ma, EJ nie jest oceniana jako gałąź energetyki o znaczeniu przyszłościowym. Powinno to być podstawą dla głębokiej refleksji odnośnie celowości uruchamiania przez Polskę od podstaw programu jądrowego, którego pierwsze efekty pozytywne odbiorcy końcowi dostrzegą za co najmniej dziesięć lat, ale z efektami negatywnymi będą się mierzyć od zaraz. Stawianie Francji jako wzorca do naśladowania zakrawa tym samym na nieporozumienie.

\section{Rozwiązania alternatywne i wnioski końcowe}

Racjonalną alternatywą dla rozwoju wielkoskalowej energetyki jądrowej jest budowa zasobu rozproszonego, wykorzystującego trzy formy:

a) Źródła energii rozproszone i rozsiane, w szczególności najtańsze OZE o zerowym koszcie zmiennym (pogodowo-zależne: PV oraz wiatrowe na lądzie, a w przyszłości także SMR)

b) Mechanizmy zarządzania zasobem rozproszonym (pracą źródeł oraz poziomem bieżącego zapotrzebowania na energię) 
c) Magazynowanie energii (technologie magazynowania energii elektrycznej, ale także sector coupling)

Jest to zarazem droga do rozwiązania kryzysu związanego z emisyjnością energetyki węglowej i konfliktu na tym tle polityki energetycznej Polski z polityką klimatyczną Komisji Europejskiej.

Co więcej:

- ze względu na postępujący spadek kosztów inwestycyjnych w źródła wiatrowe on-shore i PV oraz możliwość częściowego uniknięcia rozbudowy sieci przesyłowej, a także zerowy koszt zmienny generacji energii elektrycznej z wiatru i PV, rozwój tak rozumianej energetyki rozproszonej pozwala nie tylko na zmoderowanie ryzyk technicznych immanentnie związanych z energetyką wielkoskalową, ale także na ograniczenie presji na wzrost kosztów zaopatrzenia gospodarki i społeczeństwa w energię elektryczną, pomimo konieczności poniesienia inwestycji dedykowanych temu modelowi rozwoju sektora elektroenergetycznego;

- inwestycje rozproszone, korzystające w sposób bezpośredni z zasobów energii wiatru i słońca pozwalają w sposób niezakłócony na spełnienie warunku wystarczalności, o którym mowa w pkt 1 ad a);

- inwestycje rozproszone, finansowane przez biznes prywatny, bez konieczności gwarantowania ich przez skarb państwa, nie będą stanowiły obciążenia dla budżetu państwa, podlegającego już istotnym naprężeniom będącym skutkiem pandemii oraz wcześniejszej polityki społecznej;

- inwestycje rozproszone, realizowane sukcesywnie, pozwalają na bieżąco czerpać z efektów postępu technicznego, przy ograniczonym ryzyku negatywnych konsekwencji wyborów nietrafionych;

- inwestycje rozproszone, realizowane sukcesywnie, pozwalają uniknąć efektu skokowych zmian w dostępności, o której mowa w pkt. 1 pkt b): od deficytu grożącego załamaniem dostaw do istotnej, ale przejściowej nadwyżki, wymagającej bieżącego finansowania.

Przy analizowaniu struktury rozproszonego zasobu wytwórczego opartego na OZE należy zdecydowanie rozróżniać technologie OZE o zerowym koszcie zmiennym (wiatr on-shore i PV) od pozostałych (biomasa, geotermia) obciążonych znacznym 
kosztem operacyjnym i zagrożonych zdyskwalifikowaniem jako OZE (spalanie biomasy). Te drugie, pod pozorem przewidywalności produkcji energii, są aktualnie preferowane w mechanizmach wspierania rozwoju OZE, de facto kanibalizując środki finansowe dedykowane do rozwoju OZE i obciążając wynikowy koszt zaopatrzenia w energię.

Program PEJ, jeżeli zostałby przyjęty do realizacji, w sposób drastyczny pogłębi deficyt środków na rozwój OZE pogodowo-zależnych, pozornie obniżając presję polityczną na ten rozwój, określoną w ramach polityki klimatycznej. Jednocześnie nasili ryzyka związane z charakterem wielkoskalowej elektroenergetyki scentralizowanej, w wyniku czego nie tylko nie podniesie bezpieczeństwa energetycznego Polski, ale je dodatkowo pogorszy. 